\title{
Evaluation of Soil Loss According to Surface Covering and Tillage Methods in Com Cultivation
}

\author{
Jeong-Tae Lee*, Gye-Jun Lee, Jong-Soo Ryu, Jeom-Soon Kim, Kyung-Hwa Han', and Seok-ho Park ${ }^{1}$ \\ Highland Agriculture Research Center, National Institute of Crop Science, RDA, Pyeongchang, 232-955, Korea \\ ${ }^{1}$ National Academy of Agricultural Science, RDA, Suwon, 441-707, Korea
}

(Received: October 8 2013, Accepted: November 22 2013)

\begin{abstract}
Com was mainly cultivated in slope land during summer season when heavy rain falls so that soil loss occurs severely. Especially, soil disturbance and exposure of topsoil by conventional tillage intensifies soil loss by heavy rain. The aim of this study was to develop surface covering and tillage methods for reducing soil loss in com cultivation. The experiment was conducted in $17 \%$ sloped lysimeter with 8 treatments including strip tillage after surface covering with rye residue, strip tillage after residue covering of several crops and sod culture, black polyethylene film covering after conventional tillage and control. Amount of runoff water and eroded soil, and com growth were investigated. Amounts of runoff water in all plots except black polyethylene plot ranged from 152 to $375 \mathrm{~m}^{3} \mathrm{ha}^{-1}$, accounting for $13 \sim 32 \%$ of $1,158 \mathrm{~m}^{3} \mathrm{ha}^{-1}$ in control. Amount of eroded soil decreased by 94 to $99 \%\left(3\right.$ to $\left.89 \mathrm{~kg} \mathrm{ha}^{-1}\right)$ in plots of strip tillage after covering with crop residues compared to control with $1,739 \mathrm{~kg} \mathrm{ha}^{-1}$. Com yields in plots of strip tillage after covering with crop residues ranged from 6.0 to $6.9 \mathrm{Mg} \mathrm{ha}^{-1}$, while that of control was $6.5 \mathrm{Mg} \mathrm{ha}^{-1}$. The results suggest that strip tillage methods after surface covering with crop residues are very effective on soil conservation of slope land in com cultivation.
\end{abstract}

Key words: Corn, Covering method, Runoff water, Soil loss, Strip tillage

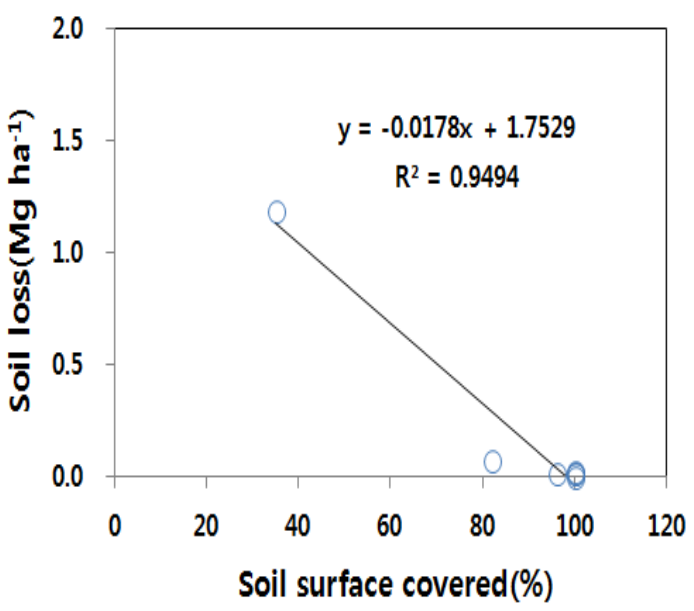

(a) Soil loss

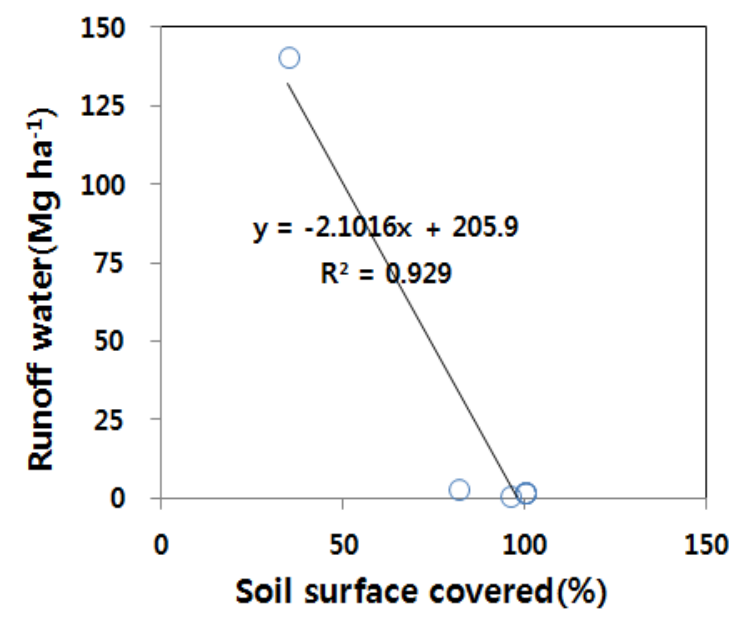

(b) Runoff water

The effects of covering on soil loss and runoff water investigated on July 13 including one rainfall event, July 11.

\footnotetext{
*Corresponding author : Phone: +82333301940, Fax: +82333301519, E-mail: leejt@korea.kr

${ }^{\S}$ Acknowledgement: This study was carried out with the support of "Cooperative Research Program for Agricultural Science \& Technology Development (Project No. PJ006430)" Rural Development Administration, Republic of korea.
} 


\section{Introduction}

백두대간을 중심으로 해발 $400 \mathrm{~m}$ 이상 지역에 위치한 고 랭지에서 영농은 대부분 산지를 개간하여 이루어져 왔기 때 문에 경사진 밭이 대부분이다. 이러한 밭에서 작물이 재배 되는 시기는 여름철 집중 강우기와 겹쳐 토양유실 위험이 매우 높다. 특히 작물을 재배하기 위하여, 우선 트랙터 부착 형 로터베이터로 전면 경운하고, 로터리 작업에 의한 포장 정지 작업 후 이랑을 조성 하는 기존의 관행경운 방법에 의 해, 표토 $15 \mathrm{~cm}$ 이내 토양의 교란이 심하고, 곱게 부스러진 토양입자는 강우에 직접 노출되어 유실 위험이 가중되는 것 으로 평가된 바 있다 (Jung et al., 1989).

경사 밭 토양보전과 관련하여 피복작물을 이용한 토양관 리 연구는 다양하게 수행되어 왔으며, 특히 호밀 등을 이용 한 토양표면의 피복과 더불어 최소경운을 도입한 작물 재배 기술은 토양유실을 현저히 줄일 수 있음이 밝혀졌다 (Duran et al., 2008, 2011; FAO, 2000). 미국 일리노이 주에서는 농가의 $50 \%$ 가 피복작물을 재배하여 잔재물로 토양을 피복 시키고, 경운을 최소화하여 작물을 재배함으로써 토양침식 을 방지할 수 있는 것으로 평가하고 있다 (Peterson, 2004). 이러한 피복작물 재배를 이용한 최소경운 기술은 관행 대비 수확량은 99\% 수준으로 거의 차이가 없지만, 비용을 $43 \%$, 노동력을 $47 \%$ 절감할 수 있는 것으로 보고되어 있다 (Luna 등, 2003). 국내의 경우도 피복작물을 이용한 경사 밭 토양 보전에 대한 많은 연구가 수행 되었으며, 토양유실 경감 효 과가 매우 높은 것으로 평가되었다 (Seo et al., 2005; Lee et al., 2005). 또한 경사 밭 토양보전을 위한 부분경운 작업
기 개발과 이에 대한 작물생산성 평가에 대한 연구결과도 일부 도출되었는데, 경사 밭에서의 최소경운에 의한 작물재 배는 토양보전 효과가 매우 높은 것으로 평가되었다 (Lee et al., 2011).

옥수수는 고랭지의 주요 작물이며 배추와 함께 토양 침 식 위험성이 높은 작물이다. 옥수수의 식생피복인자는 0.44 로 배추 (0.59)보다는 낮으나 고추 $(0.28)$, 콩 $(0.19)$ 보다는 훨씬 높아, 고랭지에 위치한 농경지에서 옥수수의 재배는 토양 퇴화와 주변 수계의 오염에 취약한 것으로 평가되고 있다 (Jung 등, 2004). 본 연구에서는 옥수수를 재배할 때, 토양 피복 및 경운 방법에 따라 유거수 유출 및 토양유실 특 성과 작물의 생산성을 평가하여 경사 밭 토양 보전농업을 위한 기초자료로 이용하고자 하였다.

\section{Materials and Methods}

시험 장소 및 작물 시험장소는 강원도 평창군 소재 국 립식량과학원 고령지농업연구센터에 설치된 무저라이시미 터 시험포장 (경도 $128^{\circ} 44^{\prime} 05^{\prime \prime}$, 위도 $37^{\circ} 40^{\prime} 38^{\prime \prime}$ )에서 2009 2010년 수행하였다. 무저라이시미터의 규격은 가로 $2.5 \mathrm{~m}$ 에 세로 $13.4 \mathrm{~m}$ 로 조성하였다. 경사는 $17 \%$ 이며 시험지 토양 특성은 Table 1과 같은데 농업과학기술원 토양분석기준 (NIAST, 2000)에 준하여 분석하였다. 시험 주작물은 옥수수 (Zea mays L.)로 품종은 미백찰 2호이었으며, 시비량은 작물별 시비처 방 기준 (NIAST, 2006)의 옥수수 표준시비량 N-P-K=186-35-74 $\mathrm{kg} \mathrm{ha}^{-1}$ 에 준하였다. 6월 8일 포장을 조성하여 6월 11일 25 일 육묘한 옥수수 묘를 재식거리 $65 \times 30 \mathrm{~cm}$ 로 정식하였으

Table 1. The physico-chemical properties of soil in experimental field.

\begin{tabular}{|c|c|c|c|c|c|c|c|c|c|c|}
\hline \multirow{2}{*}{$\begin{array}{c}\text { Soil } \\
\text { properties }\end{array}$} & \multicolumn{3}{|c|}{ Soil particle distribution } & \multirow{2}{*}{ Texture } & \multirow{2}{*}{$\mathrm{pH}$} & \multirow{2}{*}{$\mathrm{OM}$} & \multirow{2}{*}{ Av. $\mathrm{P}_{2} \mathrm{O}_{5}$} & \multicolumn{3}{|c|}{ Ex. Cations } \\
\hline & Sand & Silt & Clay & & & & & $\mathrm{K}$ & $\mathrm{Ca}$ & $\mathrm{Mg}$ \\
\hline & $\%$ & $\%$ & $\%$ & & 1: 5 & $\mathrm{~g} \mathrm{~kg}^{-1}$ & $\mathrm{mg} \mathrm{kg}^{-1}$ & & olc k & \\
\hline Value & 51.0 & 26.7 & 22.3 & Loam & 6.9 & 33 & 343 & 0.8 & 5.1 & 0.9 \\
\hline
\end{tabular}

Table 2. Soil covering methods and tillage types in experimental field.

\begin{tabular}{cccc}
\hline \hline \multirow{2}{*}{ Treatments } & & Treatment details & \\
\cline { 2 - 4 } Control & Crop residue cover & Tillage types & Sod culture \\
T1 & No & Moldboard Plowing + fragmentation & No \\
T2 & Rye & Strip tillage & Rye \\
T3 & Rye & Strip tillage & \\
T4 & Arachniodes aristata (G.Forst.) Tindale & Strip tillage & Ligularia fischeri var. spiciformis Nakai \\
T5 & Aster koraiensis Nakai & Strip tillage & Arachniodes aristata (G.Forst.) Tindale \\
T6 & Red clover & Strip tillage & Aster koraiensis Nakai \\
T7 & Black polyethylene & Strip tillage & Red clover \\
\hline
\end{tabular}


며, 시험구 배치는 라이시미터 시설의 한계로 단구제로 시 험을 수행하였다.

시험처리 내용 피복방법은 관행을 포함하여 호밀 예 취피복 (T1), 호밀 예취피복 후 초생 (T2), 곰취 초생 (T3), 고사리 초생 (T4), 벌개미취 초생 (T5), 레드클로버 초생 (T6), 비닐멀칭 (T7) 등 8처리를 두었다 (Table 2). Fig. 1과 같이 비닐멀칭과 관행 재배는 기존 경운작업 (경운-로터리-두둑 성형)으로, 호밀 예취피복 및 초생작물을 도입한 피복재배

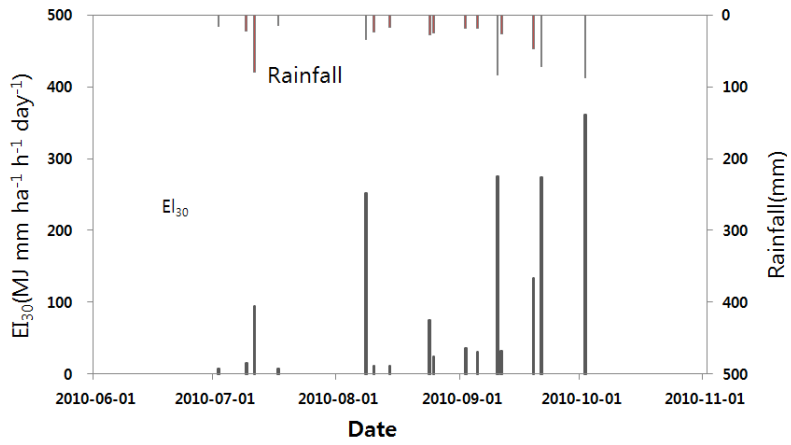

Fig. 4. Rainfall erosion index $\mathbf{E I}_{30}$ and rainfall during com growing period.
는 부분경운작업기를 이용한 최소경운 기술을 적용하였다. 부분경운작업기는 2008 년도 농촌진흥청에서 개발한 작업기 로, Fig. 2와 같이 고랭지 주요작물의 경종 특성에 맞춘 트 랙터 부착형 4 조식 작업기를 적용하였다. 부분경운작업기 는 Fig. 2(a)와 같이 $65 \mathrm{~cm}$ 간격으로 한조에 12 개의 경운날 을 부착하였으며, 경운 날은 쇄토된 토양이 부분경운 골 밖 으로 비산되는 현상을 줄이기 위해 Fig. 2(b)와 같이 직사각 형의 평면 날로 제작되었다. 일부 비산되는 토양을 부분 경 운 골로 모이도록 토양비산 방지판 (Fig. 2(c))을 로터리 후 방 덮개에 부착하였다. 경운 폭은 $10 \mathrm{~cm}$, 깊이는 $10 \sim 12 \mathrm{~cm}$ 로 작물이 재식되는 최소 부분만 경운함으로 관행 전면경운 작업 대비 토양표면의 교란을 최소화 하는 시스템으로, Lee (2012) 등이 콩 시험에 이용한 부분경운 작업기와 동일하다.

토양피복률 측정 피복률 측정 및 분석은 Kim and Park (1994)이 사용한 방법을 응용하였다. 작물 휴한기와 옥수수 생육 초기에는 옥수수와 피복작물의 생육이 이루어지는 동 안에 30 일 간격으로 처리별로 동일한 장소의 $1.5 \mathrm{~m}$ 높이에 서 사진을 촬영하여 사진에서 옥수수에 의해 피복된 면적과 피복작물에 의해 피복된 면적을 구한 후 전체 면적에 대한
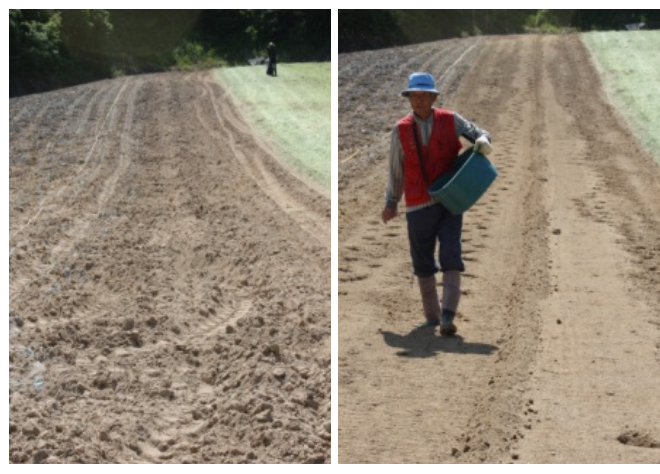

$<$ Conventional Tillage $>$

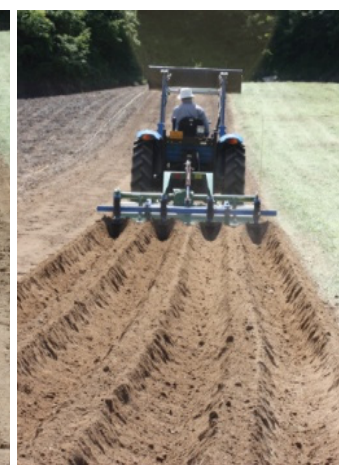

rar

\begin{abstract}
plowing and fragmentation (left), rye cutting (middle) and strip tillage only in
\end{abstract} seeding part (right).

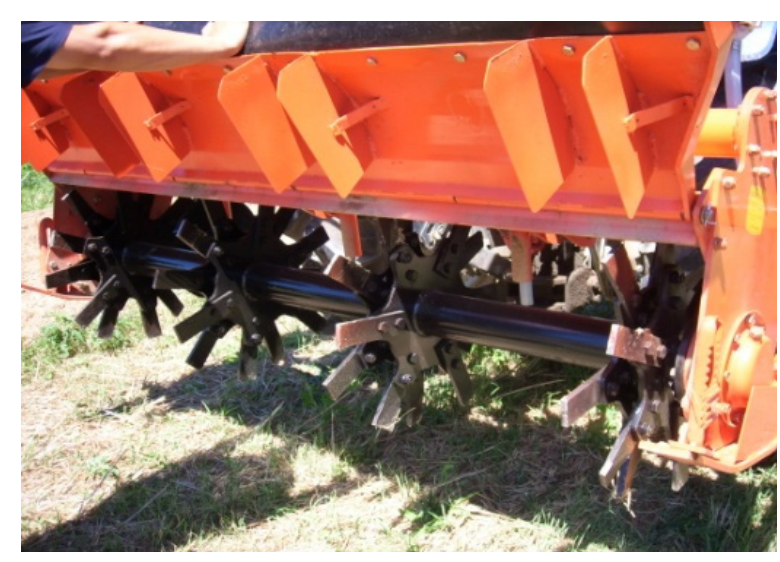

(a) Soil drift protecting plate

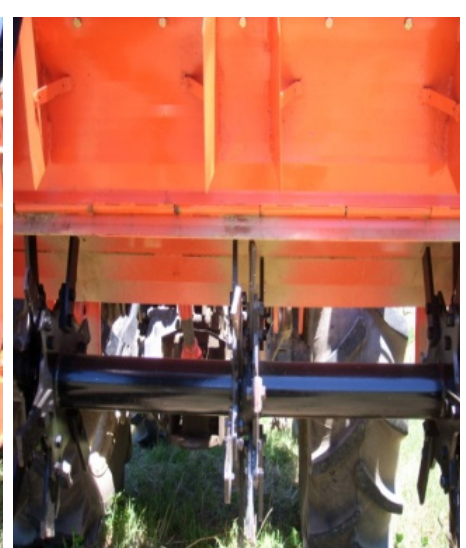

(b) Structure of rotary blade

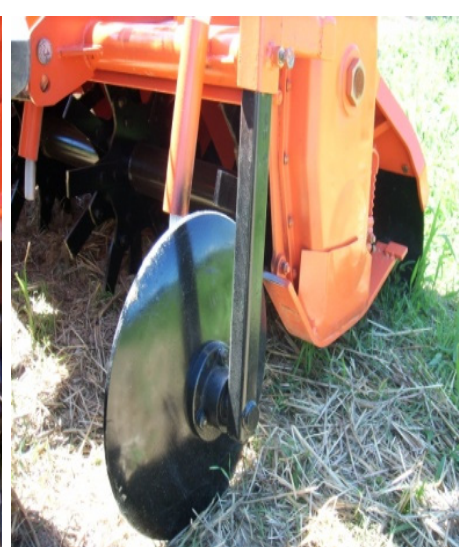

(c) Coulter

Fig. 2. The feature of tillage machine developed for reducing soil erosion. 

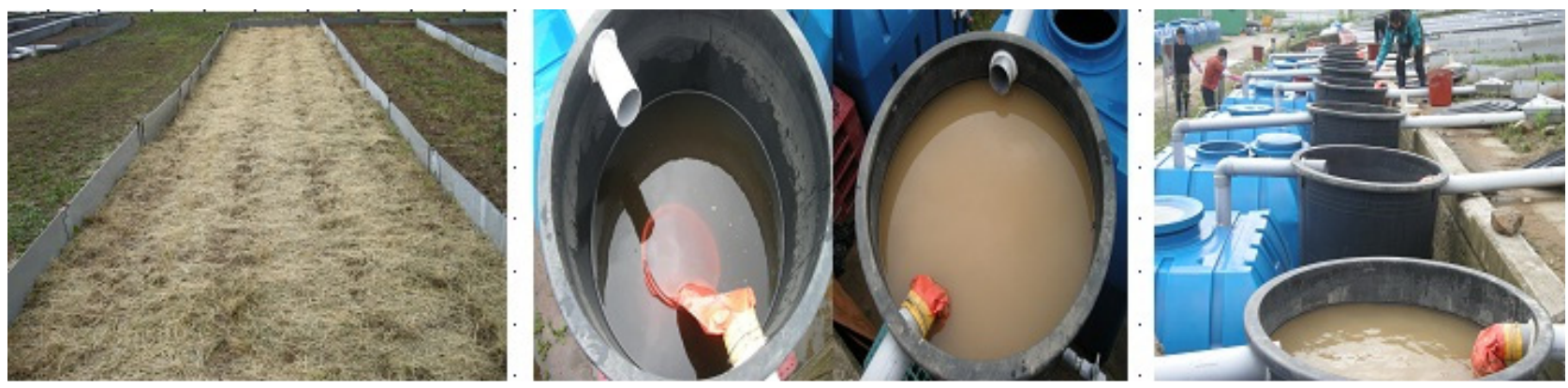

Fig. 3. Lysimeter catchment to collect runoff and soil loss in experimental plots.

비를 구하여 이를 각각의 피복률로 결정하였다. 그리고 옥 수수의 초장이 $1 \mathrm{~m}$ 이상 되는 시점인 옥수수 정식 40 일 이 후에는 달관 조사로 피복률을 결정하였다.

\section{토양유실량 및 작물생산성 평가 강우직후 유거수량} 과 토양유실량을 측정하였다. Fig. 3과 같이 각각의 라이시 미터 하단부에 설치된 집수통에 수집된 유거수는 분석용 시 료를 채취하고, 전체량을 측정 후 방류하였다. 그리고 토사 는 전량 수집하여 자연건조 후 토사량을 측정하였다. 시간 별 강우량은 대관령 기상관측소 자료를 이용하였으며, 강우 강도분석은 Foster et al. (1981)의 방법에 따라 강우에너지 $\mathrm{E}=0.119+0.0873 \log \mathrm{I}$ (I: 강우강도)에 30 분 최대강도 $\left(\mathrm{I}_{30}\right)$ 의 곱인 강우침식성인자 $\mathrm{EI}_{30}$ 으로 나타내었다 (Fig. 4). 옥수수 의 생육 및 수량은 각각의 처리구별로 상부, 중부, 하부로 나누어 3 반복으로 조사하여, 농업과학기술 연구조사분석기 준 $(\mathrm{RDA}, 2003)$ 에 준하여 수량조사를 실시하고 작물생산성 을 평가하였다.

\section{Results and Discussion}

토양피복 효과분석 피복방법에 따른 토양의 피복률 변화는 Table 3 과 같다. 옥수수 파종을 위한 포장조성작업 직후인 6월 8일 토양 피복률을 조사한 결과 관행구는 농기 계 작업에 의한 토양표면의 교란에 따라 $0 \%$ 의 피복률을 보 인 반면, 호밀예취 피복을 포함한 피복 처리구는 $62 \sim 72 \%$ 로 강우에 취약할 수밖에 없는 작물생육 초기에 토양을 피복시 키는 효과가 매우 높았다. 특히 관행의 경우 옥수수 파종 후 30 일경인 7월 10 일까지 $35 \%$ 의 피복률로 매우 낮은 경향을 보였는데, 우리나라의 기후 특성상 6 월 하순이후 장마기에 접어들어 많은 강우가 예상됨을 감안하면 이시기의 토양피 복 상태와 토양유실은 매우 높은 상관관계를 보일 것으로 판단된다. 옥수수 수확 직후 인 10월 10 일 피복률은 관행구 와 포장전면 경운에 의한 호밀 파종구, 멀칭비닐 제거구의 경우 피복률이 $0 \sim 17 \%$ 로 매우 낮은 경향을 보였다. 이와 같 은 낮은 피복 상태는 9월 이후에 발생하는 태풍 등에 의한 집중강우가 발생할 경우 토양유실 위험이 매우 높을 것으로

Table 3. Soil surface covering percentage according to different covering methods.

\begin{tabular}{cccccccc}
\hline \hline \multirow{2}{*}{ Treatments $^{\dagger}$} & \multicolumn{7}{c}{ Investigation time (month. day) } \\
\cline { 2 - 7 } & 5.10 & 6.8 & 7.10 & 8.10 & 9.10 & 10.10 \\
\hline Control & 25 & 0 & 35 & 100 & 100 & 17 \\
T1 & 85 & 71 & 100 & 100 & 100 & 0 \\
T2 & 97 & 72 & 100 & 100 & 100 & 97 \\
T3 & 32 & 62 & 96 & 100 & 100 & 54 \\
T4 & 23 & 60 & 82 & 100 & 100 & 35 \\
T5 & 75 & 66 & 100 & 100 & 100 & 92 \\
T6 & 67 & 68 & 100 & 100 & 100 & 82 \\
T7 & 11 & 65 & 72 & 100 & 100 & 2 \\
\hline
\end{tabular}

${ }^{\dagger}$ Treatments were as follows: Control, conventional tillage without covering and sod culture; T1, strip tillage after covering with rye residue; T2, strip tillage after covering with the residue and the sod culture of rye; T3, strip tillage after covering with the residue and the sod culture of Ligularia fischeri var. spiciformis Nakai; T4, strip tillage after covering with the residue and the sod culture of Arachniodes aristata (G.Forst.) Tindale; T5, strip tillage after covering with the residue and the sod culture of Aster koraiensis Nakai; T6, strip tillage after covering with the residue and the sod culture of red clover; T7, black polyethylene film covering after conventional tillage. 


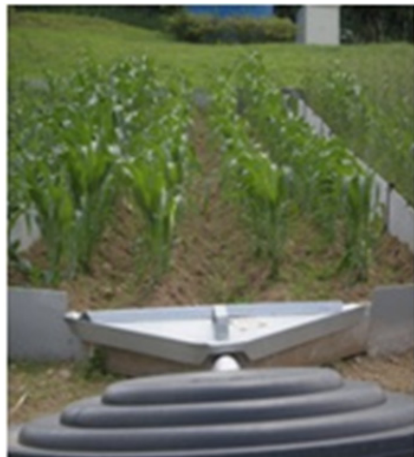

Control

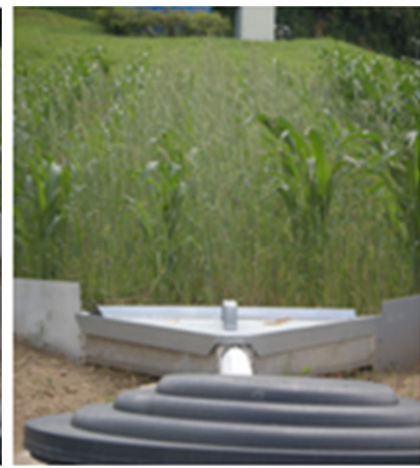

T1

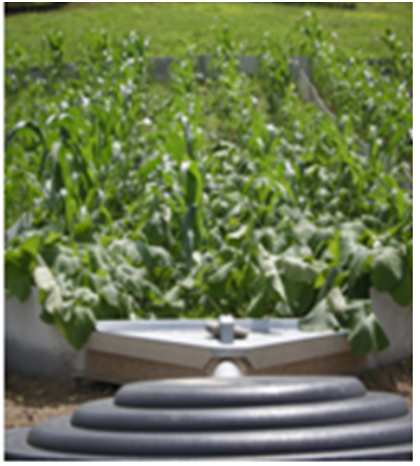

T3

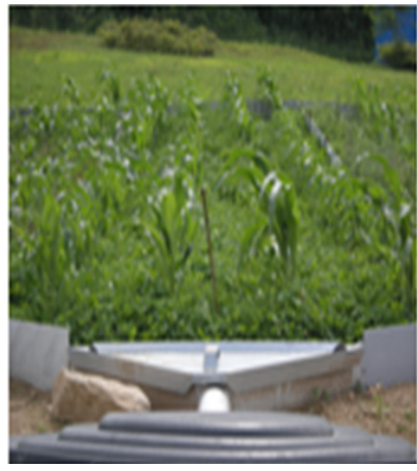

T3

Fig. 5. Soil surface covered at 30 days after sowing of com.

${ }^{\dagger}$ Treatments were as follows: Control, conventional tillage without covering and sod culture; T1, strip tillage after covering with rye residue; T3, strip tillage after covering with the residue and the sod culture of Ligularia fischeri var. spiciformis Nakai; T6, strip tillage after covering with the residue and the sod culture of red clover.

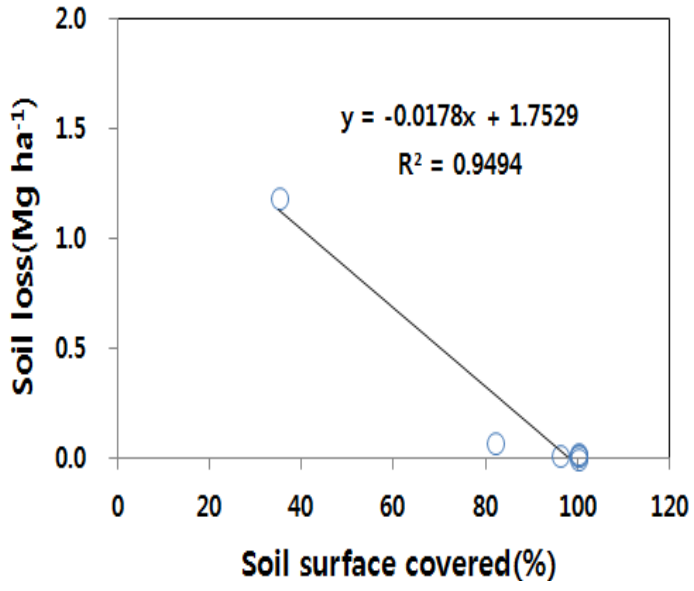

(a) Soil loss

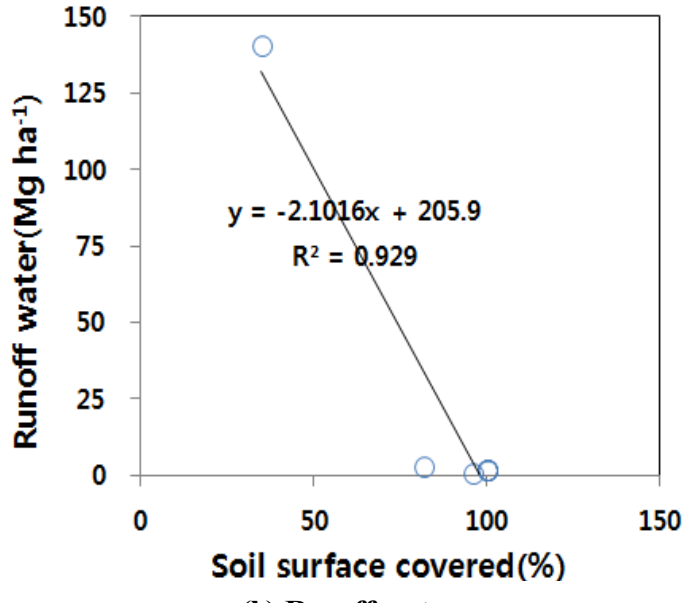

(b) Runoff water

Fig. 6. The effects of covering on soil loss and runoff water investigated on July 13 including one rainfall event, July 11.

판단되었다. 그러나 호밀 초생재배를 포함한 피복 처리구는 35 97\%로 옥수수 수확 후 나지 상태의 토양을 조기에 피복 시키는 효과가 매우 높은 경향을 보였다. Fig. 4는 시험기간 동안의 강우량 및 강우강도를 분석한 결과인데, 조사기간 동안의 강수량은 $718.4 \mathrm{~mm}$ 가 발생하여 포장에 가해졌다. 이 중 작물생육 초기인 6월 하순까지 강우가 없었으며, 옥 수수 정식 30일경인 7월 9 11일에 $115.4 \mathrm{~mm}$ 가 내려 평년 대비 강우량이 매우 적었다. 반면 생육후반기인 9월에 332.8 $\mathrm{mm}$ 의 강우가 집중되었는데, 이시기의 강우침식인자 EI30 은 $926.9 \mathrm{MJ} \mathrm{mm} / \mathrm{ha} / \mathrm{hr}$ 로 매우 높은 강도를 보였다. Fig. 5 는 옥수수 정식 후 30 일경인 7월 11일 토양피복 특성을 보 여주고 있으며, Fig. 6은 토양피복 상태에 따른 유거수 유출 및 토양유실 특성에 대한 분석결과이다. 강우가 집중되는 시기의 낮은 피복률은 토양유실의 위험을 매우 높임을 알 수 있는데, 특히 관행의 경우 농기계작업에 의해 교란된 표 토가 유실 위험을 가중시킨 것으로 평가되었다. Baver (1972)
와 Laflan (1979)은 경작지에서의 토양유실 경감방법으로 합리적인 작부체계와 토양관리가 기본이라 하였다. 이는 합 리적인 작부조합으로 토양 피복률을 증대시켜 강우의 직접 적인 타격력과 유속을 감소시키고 작물 뿌리에 의한 토양고 정과 침투율을 증가시켜 토양 유실 및 지표수 유출량을 감 소시키는데 기인한 것으로 해석된다 (Duran et al., 2008). 본 시험에서도 호밀예취피복을 포함한 부분경운 피복재배 는 관행 대비 토양표면 교란을 최소화하고, 피복작물로 토 양을 보호함으로서 토양유실을 현저히 저감할 수 있을 것으 로 평가되었다.

유거수 및 토양유실 특성 분석 피복방법에 따른 Lysimeter 내에서의 실제적인 토양유실량 평가에 대한 결과는 Table 4,5 와 같다. 처리 간 유거수 유출량은 관행에 비해 호밀예 취피복 및 호밀 초생, 벌개미취 초생, 레드클로버 초생, 곰 취 초생의 경우는 $14 \sim 32 \%$ 수준으로 유거수의 유출 경감 효 
Table 4. The amount of runoff water according to different covering methods.

\begin{tabular}{ccccc}
\hline \hline \multirow{2}{*}{ Treatments $^{\dagger}$} & \multicolumn{5}{c}{ Runoff $_{\text {water }\left(\mathrm{m}^{3} \mathrm{ha}^{-1}\right)}$} \\
\cline { 2 - 5 } Control & July & August & September & 1,158 \\
T1 & 141 & 29 & 988 & 152 \\
T2 & 2 & 3 & 147 & 375 \\
T3 & 2 & 3 & 371 & 201 \\
T4 & 1 & 2 & 198 & 362 \\
T5 & 3 & 19 & 340 & 256 \\
T6 & 2 & 5 & 249 & 267 \\
T7 & 2 & 5 & 260 & 1,326 \\
\hline
\end{tabular}

${ }^{\dagger}$ Treatments were as follows: Control, conventional tillage without covering and sod culture; T1, strip tillage after covering with rye residue; T2, strip tillage after covering with the residue and the sod culture of rye; T3, strip tillage after covering with the residue and the sod culture of Ligularia fischeri var. spiciformis Nakai; T4, strip tillage after covering with the residue and the sod culture of Arachniodes aristata (G.Forst.) Tindale; T5, strip tillage after covering with the residue and the sod culture of Aster koraiensis Nakai; T6, strip tillage after covering with the residue and the sod culture of red clover; T7, black polyethylene film covering after conventional tillage.

Table 5. The amount of soil loss according to different covering methods.

\begin{tabular}{ccccc}
\hline \hline \multirow{2}{*}{ Treatments ${ }^{\dagger}$} & \multicolumn{3}{c}{ Soil loss(kg ha $\left.{ }^{-1}\right)$} & Total \\
\cline { 2 - 5 } Control & July & August & September & 1,521 \\
T1 & 1,190 & 0 & 331 & 30 \\
T2 & 15 & 0 & 15 & 3 \\
T3 & 3 & 0 & 0 & 40 \\
T4 & 15 & 0 & 25 & 89 \\
T5 & 76 & 0 & 13 & 46 \\
T6 & 27 & 0 & 19 & 35 \\
T7 & 15 & 0 & 20 & 3,325 \\
\hline
\end{tabular}

${ }^{\dagger}$ Treatments were as follows: Control, conventional tillage without covering and sod culture; T1, strip tillage after covering with rye residue; T2, strip tillage after covering with the residue and the sod culture of rye; T3, strip tillage after covering with the residue and the sod culture of Ligularia fischeri var. spiciformis Nakai; T4, strip tillage after covering with the residue and the sod culture of Arachniodes aristata (G.Forst.) Tindale; T5, strip tillage after covering with the residue and the sod culture of Aster koraiensis Nakai; T6, strip tillage after covering with the residue and the sod culture of red clover; T7, black polyethylene film covering after conventional tillage.

과가 매우 높은 경향을 보였다. 반면 비닐멀칭의 경우에는 유거량이 관행보다 1.14배 높았는데, 이는 멀칭비닐이 침투 되는 물량을 줄임으로서 더 많은 유거수량을 보인 것으로 생각된다. 특히 시험 처리 간 동일한 조건인 상하경 재배로 시험을 수행함에 따라 유거수의 유출이 더 많았던 것으로 판단된다. 시험기간 중 토양유실은 상대적으로 강우량 및 강우강도가 제일 낮았던 7월에 가장 높은 경향을 보였는데, 전체 유실량의 $78 \%$ 이상이 이 기간에 집중되었다. 이는 토 양피복 특성과 관련된 결과로 판단되며, 옥수수 생육초기의 교란된 표토는 토양피복이 잘 형성되지 않으면 상대적으로 매우 낮은 강우강도에도 토양유실이 발생할 위험이 높은 것
으로 해석된다. 각 처리별 총 토양유실량은 관행 처리구가 $\mathrm{ha}$ 당 $1.521 \mathrm{~kg}$ 인 반면 호밀예취피복을 포함한 피복처리구 는 $89 \mathrm{~kg}$ 이하로 관행 대비 $94 \%$ 이상 토양유실 경감 효과가 있었다. 그러나 비닐멀칭의 경우에는 ha당 $3,325 \mathrm{~kg}$ 의 토양 유실이 발생하였는데, 이는 멀칭비닐 위로 덮은 토양이 유 거수와 함께 유출 되어 발생량을 증가 시킨 것으로 판단된 다. 이와 같은 연구결과는 토양 피복률을 증대 시켜주는 것 이 토양유실의 원인이 되는 강우의 직접적인 타격을 줄여 줄 수 있다는 연구결과와 동일한 결과이다 (Baver et al., 1972; Hur et al., 2005; Laflen et al., 1979; Wainwright et $\mathrm{al}$, 2000). 또한 작물 피복상태에 따른 C값 추정식 (Wischmeier 
and Smith, 1978)에 기초한 토양유실량 산정 결과 및 배추 재배기와 휴한기에 피복작물로 호밀, 헤어리베치를 재배하 여 토양 피복률을 높이는 것이 토양 유실량을 저감시킨다는 연구결과와 유사한 경향을 보였다 (Lee et al., 2005). 이러 한 결과로 볼 때 강우가 집중되는 여름철에 경사지에서 작 물을 재배할 경우 토양 보전을 위한 최우선 과제는 토양을 잘 피복하여야 하는 중요성을 암시해 주고 있다. 특히 최소 경운을 도입한 피복재배는 유거수 유출량을 저감시키면서, 토양유실 경감효과도 매우 높을 것으로 평가된다. 작물이 심겨지는 최소 부분만 경운하여 작물이 심겨지고, 미경운 부분이 피복될 경우 토양유실 경감 효과는 배가 될 것으로 판단된다. 이와 더불어 부분경운은 Lee et al. (2011)의 연구 결과에서 경운정지 작업을 생략하고 작물이 심겨지는 부분 만 1회 경운함으로써 연료소모량도 $50 \%$ 절감된다고 보고된
바 있어 경사지의 토양유실 및 농기계 연료비 절감에도 크 게 기여할 수 있을 것으로 판단된다.

\section{옥수수 생육 및 수량특성 분석 옥수수 수확기 생육} 및 수량특성은 Table 6, Fig. 7과 같은데, 수량 구성요소인 종실 수량에 있어 관행의 경우 ha당 6.5 톤 수준을 보였다. 반면 호밀 예취피복, 레드클로버 초생, 비닐멀칭 처리구는 6.7 6.9톤으로 관행보다 오히려 증수되는 결과를 보인 반 면, 호밀초생피복, 벌개미취 초생피복, 곰취 초생피복, 고 사리 초생피복의 경우는 6.0 6.4톤 수준으로 비슷하거나 약간 낮은 경향을 보였다. 이와 같은 결과는 부분 경운의 콩 수확량이 관행경운에 비해 98\%, 무경운은 96\% 수준 (Cruse, 2002), 옥수수 수확량은 관행 경운에 비해 부분 경운이 $99 \%$, 무경운이 98\% 수준 (Peterson, 2004) 이라는 기존 연구 결

Table 6. Growth status and yield of com at harvest time according to different covering methods.

\begin{tabular}{cccc}
\hline \hline Treatments $^{\dagger}$ & Plant weight & Height of trunk & Yield \\
\hline & g plant $^{-1}$ & $\mathrm{~cm}$ & $\mathrm{M}^{\mathrm{T}}$ ha $^{-1}$ \\
Control & 700 & 176 & 6.5 \\
T1 & 715 & 174 & 6.9 \\
T2 & 591 & 147 & 6.3 \\
T3 & 596 & 170 & 6.0 \\
T4 & 727 & 177 & 6.4 \\
T5 & 491 & 158 & 6.1 \\
T6 & 629 & 172 & 6.7 \\
T7 & 625 & 168 & 6.9 \\
\hline
\end{tabular}

${ }^{\dagger}$ Treatments were as follows: Control, conventional tillage without covering and sod culture; T1, strip tillage after covering with rye residue; T2, strip tillage after covering with the residue and the sod culture of rye; T3, strip tillage after covering with the residue and the sod culture of Ligularia fischeri var. spiciformis Nakai; T4, strip tillage after covering with the residue and the sod culture of Arachniodes aristata (G.Forst.) Tindale; T5, strip tillage after covering with the residue and the sod culture of Aster koraiensis Nakai; T6, strip tillage after covering with the residue and the sod culture of red clover; T7, black polyethylene film covering after conventional tillage.

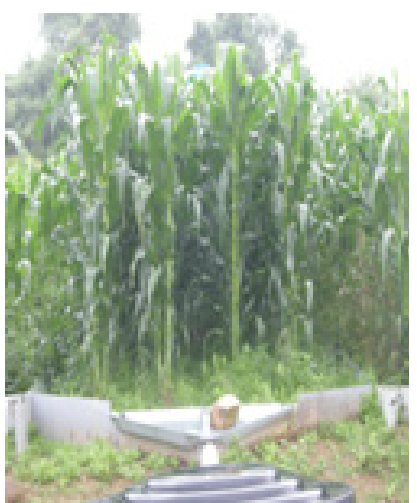

Control

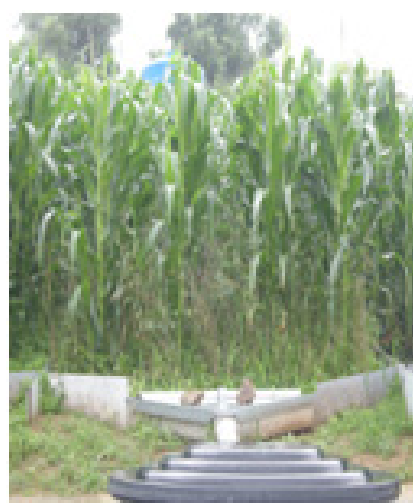

T1

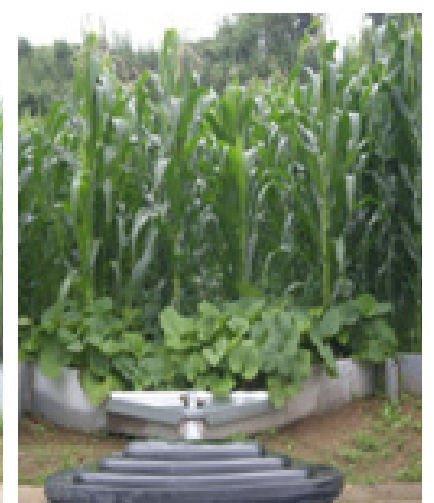

T3

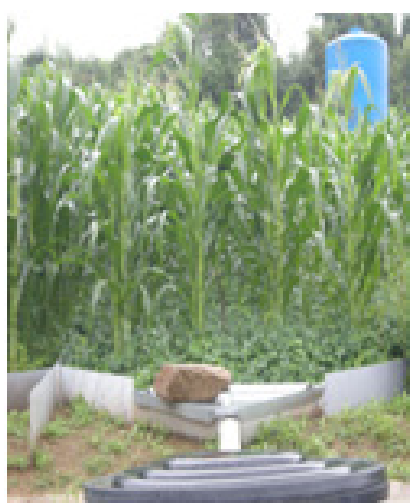

T5

Fig. 7. Experimental plots at com harvest time.

${ }^{\dagger}$ Treatments were as follows: Control, conventional tillage without covering and sod culture; T1, strip tillage after covering with rye residue; T3, strip tillage after covering with the residue and the sod culture of Ligularia fischeri var. spiciformis Nakai; T5, strip tillage after covering with the residue and the sod culture of Aster koraiensis Nakai. 
과와는 비슷한 경향이다. 또한 벼 건답직파재배에서 접촉 시비의 경우 시비량을 $50 \%$ 줄여도 관행 대비 수량이 증가된 연구 결과와 동일한 결과이다 (Park et al, 2002). 이는 동 일한 시비량으로 관행의 경우 포장 전면에 시용하고, 부분 경운의 경우 작물이 심겨지는 최소 부분에만 집중 시비함에 따른 비료 이용 효율 차이로 판단된다. 특히 작물이 아직 어 린 시기에 뿌리가 충분히 뻗지 못한 상태에서는 비료 이용 률 차이가 더 심할 것으로 판단됨에 따라 시비량 조정 등 정 밀 검토가 필요할 것으로 판단된다.

이상의 결과 토양보전과 작물의 수량을 함께 고려하여 볼 때, 작물에 따라 차이는 보이지만 호밀 예취피복의 경우 에는 작물 수량에는 영향을 미치지 않으면서 토양유실 경감 효과가 매우 높아 경사 밭 토양보전기술로 유용하게 적용되 리라 판단된다. 반면 비닐멀칭의 경우에는 작물의 생산성 증대에는 효과가 높으나, 본 시험과 같이 상하경으로 재배 할 경우에는 경사 밭의 토양유실 위험을 가중시키는 결과를 보여 이용방법에 대한 정밀한 평가가 이루어져야 할 것이 다. 경사지에서 지면 피복도에 따라 강우시 토양유실이 크 게 달라짐을 감안하면 (Jung et al, 1989; Lee et al. 2007), 토양피복은 매우 중요한 과제이다. 호밀 등은 내한성이 강 해 고랭지에서도 겨울철에 월동이 가능하여 토양의 피복효 과가 매우 높은데 (Lee et al, 2005), 작물생산성과 관련하 여 추후 정밀검정이 더 이루어져야 할 과제이다. 또한 본 시 험에 도입된 부분경운기술은 작물이 파종, 정식되는 부분만 시비가 이루어져, 관행의 포장전면시비와 달리 작물별 비료 이용 효율에 있어 다른 경향을 보일 수 있어 이에 대한 검토 도 함께 이루어져야 할 것이다. 대부분 경사지로 구성된 밭 토양 특성, 고랭지 주요작물이 강우가 집중되는 여름철에 재배됨을 감안하면, 대형농기계에 의한 표토 교란이 토양유 실 위험을 가중시키는 요인으로 농업의 지속성을 유지하기 위해서는 토양보전에 대한 지속적인 연구 및 기술도입이 이 루어져야 할 것으로 판단된다.

\section{Conclusions}

옥수수는 대부분 경사지 밭에서 비가 많은 여름철에 재 배되고 있어 토양유실 위험이 매우 높다. 특히 관행방법으 로 경운하면 토양 교란이 심하고, 토양의 피복률이 매우 낮 아 비가 많이 쏟아지면 토양유실 위험이 가중된다. 본 연구 는 옥수수 재배에서 토양유실 저감을 위한 토양피복 및 경 운방법을 개발하기 위해 수행하였다. 호밀 예취피복 후 부 분경운, 몇 가지 작물의 예취피복-부분경운 후 초생재배, 흑색 비닐멀칭과 관행경운-무피복 등 8처리를 두어 경사 $17 \%$ 내외 무저라이시메타에서 수행하였으며 유거수 및 토양 유출 특성과 옥수수 생육특성을 평가하였다. 시험결과 흑색 비닐멀칭을 제외한 모든 피복작물 예취피복 후 부분경운 처
리구에서는 유거수 유출량이 ha당 152 375 $\mathrm{m}^{3}$ 으로 관행구 의 $1,158 \mathrm{~m}^{3}$ 의 $13 \sim 32 \%$ 수준으로 감소하였다. 토양 유실량 또한 관행구가 ha당 $1,739 \mathrm{~kg}$ 인 반면, 피복작물 예취피복 후 부분경운 처리구에서는 3 89 kg으로 관행 대비 94 99\% 의 경감 효과가 있는 것으로 평가되었다. 옥수수의 이삭 수 량은 관행의 경우 ha당 6.5 톤이었는데, 피복작물 예취피복 후 부분경운 처리구들에서는 6.0 6.9 톤으로 관행과 비슷 한 경향을 보였다. 결과적으로 피복작물을 예취피복한 후 부분경운하여 옥수수를 재배하면 수량에는 큰 영향을 미치 지 않으면서 토양유실 경감효과는 매우 높아, 경사 밭 토양 보전기술로 유용하게 적용 될 수 있을 것으로 판단된다.

\section{References}

Baver, L.D., W.H. Gardner, and W.R. Gardner. 1972. Soil physics. Hohn Willey and Sons Inc.

Cruse, R.M. 2002. Strip tillage effects on crop production and soil erosion. Iowa State University.

Duran, Z.V.H. and P.C.R. Rodriguez. 2008. Soil-erosion and runoff prevention by plant covers, Review. Agron. Sustainable Dev. 28:143-149.

Duran, Z.V.H., P.C.R. Rodriguez, P.F.J. Martin, J. de Graaff. M.J.R. Francia, and D.C. Flanagan. 2011. Environmental impact of introducing plant covers in the taluses of terraces: Implications for mitigating agricultural soil erosion and runoff. Catena 84:79-88.

FAO. 2000. Manual on integrated soil management and conservation practices. FAO Land and Water Bulletin 8 ISSN pp. 1024-6073.

Foster, G.R., D.K. McCool, K.G. Renard, and W.C. Moldenhauser. 1981. Conversion of the universal soil loss equation to SI units. J. Soil Water Conserv. 36(6):355-359.

Hur, S.O., K.H. Jung, S.K. Ha, H.K. Kwak, and J.K. Kim. 2005. Mathematical description of soil loss by runoff at inclined upland of maize cultivation. Korean J. Soil Sci. Fert. 38(2): 66-71.

Jung, K.H., W.T. Kim, S.O. HUR, S.K. Ha, P.K. Jung, and Y.S. Jung. 2004. USLE/RUSLE factors for national scale soil loss estimation based on the digital detailed soil map. Korean J. Soil Sci. Fert. 37(4):199-206.

Jung, P.K, M.H. Koh, and K.T. Um. 1989. Evaluation of soil erosion management practices on sloped farm. land. Res. Rept. RDA (S\&F) 31(4):16-22.

Kim, J.T. and S.W. Park. 1994. Runoff and soil losses from sloping lands with different cropping practices. J. Korean Soc. Agric. Eng. 36(1):73-82.

Laflen, J.M. and W.C. Moldenhauer. 1979. Soil and water loss from corn-Corn rotations. Soil Sci. Am. J. 43:1213-1215.

Lee, H.H., S.K. Ha, S.O. Hur, G.H. Jung, C.W. Park, and G.H. Kim. 2007. Characteristics of soil water runoff and canopy 
cover subfactor in sloped land with different soil texture. Korean J. Soil Sci. Fert. 40(2):131-135.

Lee, J.T., G.J. Lee, C.S. Park, S.W. Hwang, and Y.R. Yeoung. 2005. Effect of hairy vetch (Vicia villosa Roth) sod culture on decreasing soil loss and providing nitrogen for Chinese cabbage in highland. Korean J. Soil Sci. Fert. 38(5):294-300.

Lee, J.T., G.J. Lee, J.S. Ryu, S.W. Hwang, S.Y. Park, Y.S. Zhang, and Y.S. Jeong. 2011. Application of reduce tillage with a strip tiller and its effect on soil erosion reduction in Chinese cabbage cultivation. Korean J. Soil Sci. Fert. 44(6): 970-976.

Lee, J.T., G.J. Lee, J.S. Ryu, J.S. Kim, S.W. Hwang, and Y.S. Zhang. 2012. Evaluation of surface covering methods for reducing soil loss of highland slope in soybean cultivation. Korean J. Soil Sci. Fert. 45(5):725-732.

Luna, J. and M. Stabel. 2003. Using strip tillage in vegetable production systems in western oregon. Oregon State University Extension Service.

NIAST (National Institute of Agricultural Science and Technology). 2000. Methods of soil and crop plant analysis. National Institute of Agricultural Science and Technology, Suwon, Korea.

NIAST (National Institute of Agricultural Science and Technology). 2006. Fertilizer Application Recommendation for Crops. p.
87-130. National Institute of Agricultural Science and Technology, Suwon, Korea.

Park, S.H., D.H. Lee, H.J. Kim, C.S. Lee, S.C. Cho, and T.Y. Kwak. 2002. Development of dry paddy seeder of strip tillage. J. Biosyst. Eng. 27(1):25-32 (In Korean).

Peterson, d. 2004. Strip-Till: The best of both worlds. University of Illinois extension, College of agricultural, Consumer and Environmental Sciences.

RDA (Rural Development Administration). 2003. Investigation and standard for agricultural experiment. p. 323-334. RDA, Suwon, Korea.

Seo, J.H., J.Y. Park, and D.Y. Song. 2005. Effect of hairy vetch on prevention of soil erosion and reduction of nitrogen fertilization in sloped upland. Korean J. Soil Sci. Fert. 38(3): 134-141.

Wainwright, J., A.J. Parsons, and A.D. Abronbams. 2000. Plot scale studies of vegetation, overland flow and erosion interactions: Case studies from Arizona and New Mexico. Hydrol. Process 14:2921-2943.

Wischmeier, W.H. and D.D. Smith. 1978. Predicting rainfall erosion losses: A guide to conservation planning. p. 58. Agricultural Handbook No. 537, USDA, Washington D.C., USA. 